Brit. J. vener. Dis. (1965), 41, 120.

\title{
SPIRAMYCIN IN THE TREATMENT OF ACUTE
}

\section{GONORRHOEA*}

\author{
BY \\ HENNING SCHMIDT AND A.-M. NIORDSON \\ Department of Dermato-venereology, Rigshospitalet (University Hospital), Copenhagen, Denmark \\ ALICE REYN \\ Neisseria Department, Statens Seruminstitut, Copenhagen, Denmark \\ MICHAEL WEIS BENTZON \\ Bio-statistical Department, Statens Seruminstitut, Copenhagen, Denmark
}

\section{Introduction}

The treatment of gonorrhoea in Denmark is as yet no serious therapeutic problem, as the majority of gonococcal infections can be cured by penicillin. Nevertheless, in an increasing number of cases a higher dosage of penicillin is required than was the case just a few years ago. At the Dermato-venereological Department of the University Hospital, a single treatment dose of 300,000 units of procaine penicillin is still used in the routine treatment of acute uncomplicated gonorrhoea. With this dose, the cure rate in 1961 was found to be approximately 98 per cent. for patients infected with penicillin-sensitive gonococci (the limit between strains with normal and reduced susceptibility was set at an in vitro concentration of $0.038 \mu \mathrm{g} . / \mathrm{ml}$.), while 300,000 units of procaine penicillin cured only 62 per cent. of those patients who were infected with gonococcal strains of reduced sensitivity (Schmidt, 1962).

Penicillin is still considered to be the drug of choice for the treatment of gonorrhoea, as it is essentially non-toxic, and when used in adequate doses results in a high cure rate. Other treatment schedules have been used, for example, penicillin in larger doses or a combination of sodium penicillin and procaine penicillin, and have given excellent results (Nielsen

\footnotetext{
* Received for publication January 26, 1965.
}

and Schmidt, 1962). The blood concentration of penicillin can also be increased by the administration of probenecid (Jensen, Kvorning, and Nørredam 1963; Schmidt and Roholt, 1965; Lomholt and Berg, 1965). An increasing number of patients report that they cannot tolerate penicillin, and even though this is presumably not so in many cases, it is preferred to withhold penicillin in such instances. Out of a total of 179 patients, mainly from the younger age groups, who attended the out-patients' department of the University Hospital in 1961 for treatment of gonorrhoea, there were 8 such patients, i.e. 4 per cent., who reported that they could not tolerate penicillin (Schmidt, 1961). Similar information has been obtained in a survey of a series of approximately 10,000 surgical patients (Foged, 1958). A reduction in the penicillin-susceptibility of gonococci involves the risk of several patients requiring a higher dose of penicillin, so that the appearance of new therapeutic agents is of considerable interest.

Spiramycin NFN, isolated in 1954 by PinnertSindico from Streptomyces ambofaciens, is among the more recent drugs which have been found effective against gonococci. Administered perorally, the substance was found to be effective against infections caused by staphylococci, certain streptococci, and gonococci. Willcox (1956) concluded that 
spiramycin in multiple doses totalling 4-12 g., given orally over 1 to 2 days, gives excellent results in the treatment of gonorrhoea. It would also cure the disease in single doses of 3-4 g., although evidence presented was a little less firm. The percentage of cures obtained with single doses of $2 \mathrm{~g}$. was unsatisfactory; 54 males were treated with single doses. David and Porter (1958-59) treated 19 males with a single dose of $2 \mathrm{~g}$.; the cure rate was $84 \cdot 2$ per cent.

Siboulet and Durel (1961) were the first to test spiramycin clinically as a "one minute treatment" in a high number of cases of acute uncomplicated gonorrhoea-in 784 men and 58 women. The treatment consisted of 10 tablets each of $250 \mathrm{mg}$., i.e. $2.5 \mathrm{~g}$., administered in the presence of the physician; the cure rate was reported as approximately 97 per cent. in men and approximately 98 per cent. in women. In this series, the diagnosis in the men was made by direct microscopy, and the investigation did not include the culture of discharge. A total of 61 strains had been previously isolated, however, and their in vitro susceptibility to spiramycin was determined; 98 per cent. of the strains required less than $1 \mu \mathrm{g}$./ml. for total inhibition (Roiron, RasettiNicod, and Durel, 1961). In 13 patients treated with a single dose of $2.5 \mathrm{~g}$., the serum concentration after 2,4 , and 6 hours was on the average $1-2 \mu \mathrm{g} . / \mathrm{ml}$.

Comparing several antibiotics in the treatment of gonorrhoea in males, Clarke (1964) found that spiramycin was superior to penicillin. All of his patients were African negroes. The cure rate after penicillin was found to be 67.4 per cent., as compared with 82.2 per cent. for spiramycin in a single dose of $2 \cdot 5 \mathrm{~g}$. No culture studies were reported from these cases. Aurangabadkar and Yawalkar (1964) treated 32 males with a single dose of $3 \mathrm{~g}$. spiramycin perorally with a cure rate of $87 \cdot 5$ per cent.

In the autumn of 1963 spiramycin was used routinely in the Dermato-venereological Department of the University Hospital in the treatment of patients with acute uncomplicated gonorrhoea; the purpose was to estimate the properties of the agent, with a view to employing it in patients with penicillin allergy and as an alternative drug in cases where penicillin treatment presented difficulties, such as the occurrence of gonococcal strains with strongly reduced susceptibility.

\section{Material and Methods}

During the period August to November, 1963, a total of 96 patients, 30 women and 66 men, with acute, newly diagnosed, uncomplicated gonorrhoea received treatment with spiramycin. The treatment consisted of 10 tablets of $250 \mathrm{mg}$. taken with two glasses of water in the presence of the physician. The patients were not specially selected, as almost all those in whom the diagnosis of uncomplicated gonorrhoea was made during the period in question received this treatment.

Swabs were taken from the urethra in men and from the urethra, cervix, and rectum in women. The swabs were sent the same day, in Stuart's medium, to the Neisseria Department, Statens Seruminstitut, where plates were inoculated immediately. Direct microscopy was carried out on methylene blue-stained smears from all the men and from 27 women. When gonococci were found by direct microscopy the above treatment was immediately instituted; otherwise the return of a positive culture report was awaited.

In Statens Seruminstitut, susceptibility tests were carried out on the isolated strains as follows: spiramycin (Rovamycin, M \& B), penicillin (penicillin G, Leo), streptomycin (di-hydrostreptomycin, Leo), and tetracycline (tetracycline hydrochloride, Lepetit), with the aid of the plate dilution method, using two-fold dilution steps for spiramycin, four-fold dilution steps for penicillin and tetracycline, and only one concentration $(25 \mu \mathrm{g}$. $/ \mathrm{ml}$.) for streptomycin. The results are given as 50 per cent. inhibiting concentration in $\mu \mathrm{g} . / \mathrm{ml}$. medium $\left(\mathrm{IC}_{50}\right)$. As a rule, 100 per cent. inhibition is obtained by twice as high a concentration (Reyn, 1961a and b; Reyn, Bentzon, and Ericsson, 1963). The precision of the susceptibility tests with regard to spiramycin was examined by repeat determination on the same specimen, and by determination on two different specimens from the same patient. The standard deviation of the difference between the results obtained by duplicate determination on 36 specimens was found to be $s_{d}=0.13$ $\left(\log \mathrm{IC}_{50}\right)$. A determination on two different specimens from 8 patients, 5 of whom belonged to pilot investigations, gave the result $s_{d}=0 \cdot 10$. The two estimates of the standard deviation are not significantly different. The final estimate was $0 \cdot 12$, which corresponds to the precision with which $\log \mathrm{IC}_{50}$ can be determined for other antibiotics, by means of the plate dilution method using two-fold dilution steps (Reyn and Bentzon, 1963).

As a control of the treatment, the aim was to obtain two negative post-treatment cultures in men and three in women. Blood specimens for serological tests for gonorrhoea (GR) were taken on the first visit.

\section{Results}

Table I shows the distribution of the 96 patients with regard to age and sex. It is seen that half of the infected women were "teenagers", while the majority

TABLE I

96 GONORRHOEA PATIENTS GROUPED ACCORDING TO AGE AND SEX

\begin{tabular}{|c|c|c|c|c|c|c|}
\hline \multirow{2}{*}{$\begin{array}{c}\text { Age } \\
\text { (yrs) }\end{array}$} & \multicolumn{2}{|c|}{ Men } & \multicolumn{2}{|c|}{ Women } & \multicolumn{2}{|c|}{ Total } \\
\hline & No. & $\begin{array}{c}\text { Per } \\
\text { cent. }\end{array}$ & No. & $\begin{array}{l}\text { Per } \\
\text { cent. }\end{array}$ & No. & $\begin{array}{c}\text { Per } \\
\text { cent. }\end{array}$ \\
\hline $\begin{array}{l}15-19 \\
20-24 \\
25-29\end{array}$ & $\begin{array}{r}5 \\
30 \\
6\end{array}$ & $\begin{array}{r}8 \\
45 \\
9\end{array}$ & $\begin{array}{r}15 \\
10 \\
2\end{array}$ & $\begin{array}{r}50 \\
33 \\
7\end{array}$ & $\begin{array}{r}20 \\
40 \\
8\end{array}$ & $\begin{array}{l}21 \\
42 \\
8\end{array}$ \\
\hline $\begin{array}{l}30 \text { and } \\
\text { over }\end{array}$ & 25 & 38 & 3 & 10 & 28 & 29 \\
\hline Total & 66 & 100 & 30 & 100 & 96 & 100 \\
\hline
\end{tabular}


of the infected men were in the age-group 20-24 years. A similar distribution was found in Lind's material for 1962 (Lind, 1964).

As stated, cultures were made in all cases to verify or to establish the diagnosis, but where direct microscopy of discharge showed gonococci (methylene blue stain), treatment was instituted immediately. As in previous investigations direct microscopy was positive in the majority of male patients, and in all those cases where direct microscopy gave a positive result $(64=97$ per cent.), the result of culture was also positive. In the remaining two men microscopy was negative, but the cultures were positive.

Direct microscopy of preparations stained with methylene blue showed gonococci in only 5 of 27 women so tested; in the remaining 22 women the diagnosis was not made until the results of culture were obtained. Direct microscopy thus gave the diagnosis in only about 20 per cent. of the cases, in agreement with the results previously reported from the same clinic (Schmidt, 1962).

TABLE II

OCCURRENCE OF GONOCOCCI ON CULTURE FROM

\begin{tabular}{|c|c|c|c|}
\hline \multicolumn{3}{|c|}{ Site } & \multirow{2}{*}{ No. } \\
\hline Urethra & Cervix & Rectum & \\
\hline $\begin{array}{l}\frac{+}{+} \\
\frac{1}{+}\end{array}$ & $\begin{array}{l}\overline{+} \\
+ \\
+ \\
+ \\
+\end{array}$ & $\begin{array}{l}- \\
\overline{-} \\
\overline{+} \\
+ \\
+\end{array}$ & $\begin{array}{r}2 \\
8 \\
14 \\
2 \\
1 \\
3\end{array}$ \\
\hline Total & $\ldots$ & .. & 30 \\
\hline
\end{tabular}

Cultures were made from the urethra, cervix, and rectum in all 30 women, and Table II shows the distribution of gonococci from these different sites. In 6 women ( 20 per cent.) gonococci were demonstrated in the rectum, and in 2 the rectum was the sole site from which gonococci were cultured. In 9 women gonococci were demonstrated in the cervix without being found simultaneously in the urethra; in 2 women gonococci were found in the urethra, and not in the cervix, while in 17 , gonococci were present in both urethra and cervix. The serological studies showed that of the 30 women in the series, 6 (20 per cent.) had a positive GR, while 9 of the men (14 per cent.) had a positive GR. Wassermann reaction was negative in all patients.

The series includes 7 infective pairs or so-called "true" partners, who reported each other mutually as contacts (Schmidt and Olesen Larsen, 1962). The susceptibility patterns of the isolated gonococci from both partners are set out in pairs in Table III for the four antibiotics. The figure for the male partner is quoted first in the case of each infective pair.
TABLE III

SUSCEPTIBILITY PATTERN FOR SPIRAMYCIN, PENICILLIN, STREPTOMYCIN, AND TETRACYCLINE IN GONOCOCCI ISOLATED FROM PATIENT AND CONTACT IN 7 TRUE PARTNERS

\begin{tabular}{|c|c|c|c|c|}
\hline $\begin{array}{l}\text { Patient } \\
\text { No. }\end{array}$ & Spiramycin & Penicillin & $\begin{array}{c}\text { Strepto- } \\
\text { mycin }\end{array}$ & $\begin{array}{l}\text { Tetra- } \\
\text { cycline }\end{array}$ \\
\hline $\begin{array}{l}109 \\
119\end{array}$ & $\begin{array}{l}0 \cdot 141^{*} \\
0.168\end{array}$ & $\begin{array}{l}0 \cdot 106 \\
0 \cdot 106\end{array}$ & $\begin{array}{l}<25 \\
<25\end{array}$ & $\begin{array}{l}0.28 \\
0.40\end{array}$ \\
\hline $\begin{array}{l}121 \\
163\end{array}$ & $\begin{array}{l}1 \cdot 13 \\
1 \cdot 60\end{array}$ & $\geqslant 1 \cdot 2$ & $\begin{array}{l}\geqslant 25 \\
\geqslant 25\end{array}$ & $\begin{array}{l}1.6 \\
1.6\end{array}$ \\
\hline $\begin{array}{l}132 \\
183\end{array}$ & $\begin{array}{l}0 \cdot 100 \\
0 \cdot 084\end{array}$ & $\begin{array}{l}0.0066 \\
0.0066\end{array}$ & $\begin{array}{l}<25 \\
<25\end{array}$ & $\begin{array}{l}0.2 \\
0.14\end{array}$ \\
\hline $\begin{array}{l}135 \\
155\end{array}$ & $\begin{array}{l}0 \cdot 168 \\
0 \cdot 168\end{array}$ & $\begin{array}{l}0.0066 \\
0.0066\end{array}$ & $\begin{array}{l}<25 \\
<25\end{array}$ & $\begin{array}{l}0 \cdot 14 \\
0.14\end{array}$ \\
\hline $\begin{array}{l}151 \\
149\end{array}$ & $\begin{array}{l}0 \cdot 141 \\
0 \cdot 119\end{array}$ & $\begin{array}{l}0.075 \\
0.106\end{array}$ & $\stackrel{25}{\geqslant 25}$ & $\begin{array}{l}0.8 \\
0.8\end{array}$ \\
\hline $\begin{array}{l}167 \\
174\end{array}$ & $\begin{array}{l}0.95 \\
0.48\end{array}$ & $\begin{array}{l}0 \cdot 30 \\
0 \cdot 30\end{array}$ & $\begin{array}{l}\geqslant 25 \\
\geqslant 25\end{array}$ & $\begin{array}{l}1.6 \\
1.6\end{array}$ \\
\hline $\begin{array}{l}188 \\
171\end{array}$ & $\begin{array}{l}0 \cdot 80 \\
0.40\end{array}$ & $\begin{array}{l}0.30 \\
0.42\end{array}$ & $\begin{array}{l}\geqslant 25 \\
\geqslant 25\end{array}$ & $\begin{array}{l}1.6 \\
1.6\end{array}$ \\
\hline
\end{tabular}

* 50 per cent. inhibitory concentration in $\mu \mathrm{g} . / \mathrm{ml}$. medium

The Table shows that the greatest variation between the susceptibility patterns for patient and contact corresponds to a two-fold dilution step.

As stated, 96 patients underwent treatment with spiramycin $2 \cdot 5 \mathrm{~g}$., but 18 patients failed to return to the University Hospital for control. Of the remaining 78 patients who underwent control at the University Hospital 65 were cured (83 per cent.) The difference between the cure rates in females and males $(22 / 23=$ 96 per cent. against $43 / 55=78$ per cent.) is not statistically significant.

Of the 13 uncured patients, 12 were men and one was a woman. All uncured cases were considered to be relapses. They appeared in the clinic from 3 to 17 days after treatment, and 10 of the 13 failures appeared within the first week after treatment. The susceptibility patterns in one of the male patients should be mentioned in particular, as repeated susceptibility tests suggest that the gonococcal strain in this patient changed its susceptibility to spiramycin during the treatment with this substance, since the patient denied exposure to renewed infection during the period of observation. Table IV shows the susceptibility pattern and treatment in this patient.

TABLE IV

SUSCEPTIBILITY PATTERN AND TREATMENT IN 1 PATIENT $\mathrm{IC}_{50}(\mu \mathrm{g} . / \mathrm{ml}$.

\begin{tabular}{c|c|c|c|c}
\hline Date & $\begin{array}{c}\text { Spira- } \\
\text { mycin }\end{array}$ & $\begin{array}{c}\text { Peni- } \\
\text { cillin }\end{array}$ & $\begin{array}{c}\text { Strepto- } \\
\text { mycin }\end{array}$ & $\begin{array}{c}\text { Tetra- } \\
\text { cycline }\end{array}$ \\
\hline $\begin{array}{c}\text { August 1, 1963 } \because .5 \mathrm{~g} . \\
\text { Treatment with } 2 \cdot 5 \\
\text { spiramycin }\end{array}$ & $0 \cdot 168$ & $0 \cdot 21$ & $\geqslant 25$ & $1 \cdot 13$ \\
\hline $\begin{array}{c}\text { August 13, 1963..2.5 g. } \\
\text { Treatment with 2.5 g. } \\
\text { spiramycin: not cured }\end{array}$ & $1 \cdot 13$ & $0 \cdot 21$ & $\geqslant 25$ & $1 \cdot 60$ \\
\hline
\end{tabular}


It appears from the Table that the spiramycin susceptibility altered, as $\mathrm{IC}_{\overline{5} 0}$ on second examination was seven times as high as on first examination. The difference in the logarithmic titre value was $0 \cdot 85$, i.e. $7 \cdot 1$ times the standard error. Unfortunately, no susceptibility determination for spiramycin was made on the third examination, but the susceptibility with regard to the other three antibiotics remained unchanged.

This patient was not cured by treatment with Reverin (Hoechst) $350 \mathrm{mg}$. daily for 2 days. Cure was finally obtained after treatment with procaine penicillin $1 \cdot 2$ mega units plus sodium penicillin 1 mega unit daily for 3 days.

\section{TABLE $\mathrm{V}$}

TREATMENT OF 12 PATIENTS WHO WERE NOT CURED AFTER SPIRAMYCIN

\begin{tabular}{|c|c|c|}
\hline Preparation and Dose & $\begin{array}{l}\text { No. of } \\
\text { Patients }\end{array}$ & Result \\
\hline Procaine penicillin 0.3 mega units $\ldots$ & 1 & Defaulted \\
\hline $\begin{array}{l}\text { Sodium penicillin } 1 \text { mega unit plus pro- } \\
\text { benecid } 1 \mathrm{~g} . \times 4 \text { daily for } 3 \text { days }\end{array}$ & 1 & Cured \\
\hline $\begin{array}{l}\text { Sodium penicillin } 1 \text { mega unit plus procaine } \\
\text { penicillin } 0.6 \text { mega units for } 3 \text { days } \ldots\end{array}$ & 1 & Cured \\
\hline $\begin{array}{l}\text { Sodium penicillin } 1 \text { mega unit plus procaine } \\
\text { penicillin } 1.2 \text { mega units }\end{array}$ & 7 & Cured \\
\hline Reverin (Hoechst) $350 \mathrm{mg}$. daily for 2 days & 1 & Cured \\
\hline Dihydrostreptomycin $1 \mathrm{~g}$. daily for 2 days & 1 & Cured \\
\hline
\end{tabular}

Gonococcal strains from three of the remaining uncured 12 patients were examined twice with spiramycin, with identical results. The sero-reaction for gonorrhoea, which was examined in 11 of these 12 patients, was positive in 4 cases. Table $\mathrm{V}$ shows the subsequent treatment which cured 11 of the patients after the failure with spiramycin. One patient defaulted.
The final series of 78 patients was first divided into three groups according to the degree of spiramycin susceptibility (Table VI; Groups I, II, III, the limits are arbitrary), and a relationship sought between the degree of spiramycin susceptibility and cure rate. Only a very slight tendency to correlation could be observed, however, and when the material was further divided according to the susceptibility to penicillin, any trace of correlation between spiramycin susceptibility and cure disappeared, as the treatment failed with approximately the same frequency within the three groups showing differing susceptibility to spiramycin. On the other hand, a pronounced correlation was found between reduced penicillin susceptibility and treatment failure. A total of 49 patients who were infected with gonococcal strains of varying spiramycin sensitivity, but all sensitive to penicillin, were all cured with spiramycin $(2 \cdot 5 \mathrm{~g}$.). The remaining 29 patients were infected with gonococcal strains possessing reduced susceptibility to penicillin; as mentioned, 13 of these ( 45 per cent.) were not cured by spiramycin treatment. The correlation between reduced penicillin susceptibility and treatment failure cannot be demonstrated in females, of whom only one did not recover.

In order to estimate whether the $\mathrm{IC}_{50}$ values for the various antibiotics examined showed any mutual correlation, the 96 strains isolated were grouped according to their susceptibility to penicillin, streptomycin, and tetracycline (Table VII).

In Group 1, where all 56 strains are susceptible to penicillin, streptomycin, and tetracycline, 15 strains (27 per cent.) show a reduced susceptibility to spiramycin. Group 2 (reduced susceptibility to penicillin) shows, as a whole, a significantly greater

TABle VI

RESULTS OF TREATMENT IN RELATION TO SUSCEPTIBILITY TO SPIRAMYCIN AND PENICILLIN IN 78 GONOCOCCAL STRAINS ISOLATED FROM CONTROLLED GONORRHOEA PATIENTS

\begin{tabular}{|c|c|c|c|c|c|c|c|c|c|c|c|}
\hline \multirow{3}{*}{ Group } & \multicolumn{5}{|c|}{ Spiramycin $\mathrm{IC}_{50}$} & \multirow{2}{*}{\multicolumn{3}{|c|}{ Penicillin }} & \multirow{2}{*}{\multicolumn{3}{|c|}{ Penicillin }} \\
\hline & \multirow{2}{*}{$\mu \mathrm{g} . / \mathrm{ml}$. } & \multirow{2}{*}{ Defaulted } & \multicolumn{3}{|c|}{$\begin{array}{c}\text { Total } \\
\text { (Ignoring Susceptibility to } \\
\text { Penicillin) }\end{array}$} & & & & & & \\
\hline & & & Cured & Not cured & Total & Cured & $\begin{array}{c}\text { Not } \\
\text { cured }\end{array}$ & Total & Cured & Not Cured & Total \\
\hline I & $\begin{array}{l}\leq 0 \cdot 050 \\
0 \cdot 059-0 \cdot 100 \\
0 \cdot 119-0 \cdot 200\end{array}$ & $\begin{array}{l}1 \\
2 \\
2\end{array}$ & $\left.\begin{array}{r}0 \\
2 \\
19\end{array}\right\} 21$ & $\left.\begin{array}{l}0 \\
1 \\
2\end{array}\right\} 3(13 \%)$ & $\left.\begin{array}{r}0 \\
3 \\
21\end{array}\right\} 24$ & $\left.\begin{array}{r}0 \\
2 \\
13\end{array}\right\} 15$ & $\begin{array}{l}0 \\
0 \\
0\end{array}$ & $\left.\begin{array}{r}0 \\
2 \\
13\end{array}\right\} 15$ & $\left.\begin{array}{l}0 \\
0 \\
6\end{array}\right\} 6$ & $\left.\begin{array}{l}0 \\
1 \\
2\end{array}\right\} 3(33 \%)$ & $\left.\begin{array}{l}0 \\
1 \\
8\end{array}\right\} 9$ \\
\hline II & $\begin{array}{l}0.24-0.40 \\
0.48-0.80\end{array}$ & $\begin{array}{l}4 \\
9\end{array}$ & $\left.\begin{array}{l}22 \\
19\end{array}\right\} 41$ & $\left.\begin{array}{l}3 \\
6\end{array}\right\} 9(18 \%)$ & $\left.\begin{array}{l}25 \\
25\end{array}\right\} 50$ & $\left.\begin{array}{l}22 \\
12\end{array}\right\} 34$ & $\begin{array}{l}\mathbf{0} \\
\mathbf{0}\end{array}$ & $\left.\begin{array}{l}22 \\
12\end{array}\right\} 34$ & $\left.\begin{array}{l}0 \\
7\end{array}\right\} 7$ & $\left.\begin{array}{l}3 \\
6\end{array}\right\} 9(56 \%)$ & $\left.\begin{array}{r}3 \\
13\end{array}\right\} 16$ \\
\hline III & $>0.95$ & 0 & 3 & $1(25 \%)$ & 4 & 0 & 0 & 0 & 3 & $1(25 \%)$ & 4 \\
\hline Women & & 7 & 22 & 1 & 23 & 17 & 0 & 17 & 6 & 1 & 7 \\
\hline Men .. & & 11 & 43 & 12 & 55 & 32 & 0 & 32 & 10 & 12 & 22 \\
\hline Total & & 18 & 65 & $13(20 \%)$ & 78 & 49 & 0 & 32 & 16 & $13(45 \%)$ & 29 \\
\hline
\end{tabular}


TABLE VII

SUSCEPTIBILITY TO SPIRAMYCIN OF 96 GONOCOCCAL STRAINS SET IN RELATION TO DIFFERENT "SUSCEPTIBILITY PATTERNS" WITH RESPECT TO PENICILLIN, STREPTOMYCIN, AND TETRACYCLINE

\begin{tabular}{|c|c|c|c|c|c|c|c|c|}
\hline \multirow{2}{*}{ Group } & \multirow{2}{*}{ Penicillin } & \multirow{2}{*}{ Streptomycin } & \multirow{2}{*}{ Tetracycline } & \multirow{2}{*}{ No. of Strains } & \multicolumn{4}{|c|}{ Spiramycin } \\
\hline & & & & & $l s^{*}$ & Pẹ cent. & st & Per cent. \\
\hline 1 & $s$ & $s$ & $s$ & 56 & 15 & 27 & 41 & 73 \\
\hline $\begin{array}{l}2 a \\
2 b \\
2 c \\
2 d\end{array}$ & $\begin{array}{l}l s \\
l s \\
l s \\
l s\end{array}$ & $\begin{array}{l}s \\
r \neq \\
s \\
r\end{array}$ & $\begin{array}{l}s \\
s \\
l s \\
l s\end{array}$ & $\begin{array}{r}16 \\
11 \\
2 \\
11\end{array}$ & $\begin{array}{r}10 \\
3 \\
1 \\
9\end{array}$ & $\begin{array}{c}63 \\
27 \\
(50) \\
82\end{array}$ & $\begin{array}{l}6 \\
8 \\
1 \\
2\end{array}$ & $\begin{array}{c}27 \\
63 \\
(50) \\
18\end{array}$ \\
\hline $2 a-2 d$ & $l s$ & & & 40 & 23 & 58 & 17 & 42 \\
\hline Total & $\ldots$ & $\ldots$ & $\ldots$ & 96 & 38 & 40 & 58 & 60 \\
\hline
\end{tabular}

The limits for the various grades of susceptibility are as follows:

$I_{\text {so }}$ for:

$\begin{array}{lll}\text { Spiramycin } & \leqslant 0.40 \mu \mathrm{g} . / \mathrm{ml} . & =\text { susceptible }(s) \\ \text { Penicillin } & \leqslant 0.038 \mu \mathrm{g} . / \mathrm{ml} . & =\text { susceptible }(s) \\ \text { Streptomycin } & \leqslant 25 \mu \mathrm{g} . / \mathrm{ml} . & =\text { susceptible }(s) \\ \text { Tetracycline } & \leqslant 0.80 \mu \mathrm{g} . / \mathrm{ml} . & =\text { susceptible }(s)\end{array}$

$\begin{array}{ll}\geqslant 0.48 \mu \mathrm{g} . / \mathrm{ml} . & =\text { less susceptible }(l s) \\ \geqslant 0.053 \mu \mathrm{g} . / \mathrm{ml} . & =\text { less susceptible }(l s) \\ \geqslant 25 \mu \mathrm{g} . / \mathrm{ml} . & =\text { resistant } \\ \geqslant 1.13 \mu \mathrm{g} . / \mathrm{ml} . & =\text { less susceptible }(l s)\end{array}$

frequency of strains with reduced susceptibility to spiramycin ( 63 per cent.; $P=0.5$ per cent.). Within the groups $2 a-d$, the only significant difference is that between $2 b$ and $2 d(\mathrm{P}=3 \cdot 0$ per cent.).

\section{Discussion}

This material confirms previous observations by Schmidt (1961) regarding age distribution, relation between the results of microscopy and culture, the occurrence of gonococci from the various sites in women, and the serological findings. The present investigation has likewise shown that the susceptibility pattern in "true" partners is very nearly identical, as the susceptibility of the gonococcal strains in question differs at most by a single two-fold dilution step, thus agreeing with previous reports by Schmidt and Olesen Larsen (1962) and Reyn and Bentzon (1963).

The original aim of the study was to investigate the possibility of using spiramycin as an alternative to penicillin in the treatment of acute uncomplicated gonorrhoea. The results show that the cure rate with spiramycin is considerably lower than that found by other authors (Siboulet and Durel, 1961). This might be due to a difference in the susceptibility of the gonococcal strains in the different series, a point which cannot be clarified, as susceptibility tests are missing in the case of the earlier studies. As mentioned below, in the present study it appears that the cure rate following spiramycin treatment is dependent only on the in vitro susceptibility to penicillin. It might be that the higher cure rates obtained by the French workers were due to the fact that in treating gonorrhoea penicillin has been used to a comparatively low degree in France and in North Africa. The cure ratẹs obtained by Willcox (1956), Clarke (1964), and Aurangabadkar and Yawalkar (1964) with a dosage of $2 \cdot 5-3 \mathrm{~g}$. spiramycin are of the same order of magnitude as that reported in the present paper.

The present material shows that the cure rate following spiramycin treatment (83 per cent.) does not differ from that found in previous series from the same clinic after a dose of 300,000 units of procaine penicillin. If all those who defaulted were in fact cured, and therefore did not attend subsequently, the figure would be 86 per cent. As this series consists of out-patients, it is possible that the treatment failures were actually due to re-infection in spite of an injunction against coitus during the period of treatment. In one patient, who denied the possibility of reinfection, susceptibility tests were performed twice during the period of investigation and it was found that the sensitivity to spiramycin had altered to a considerable degree. Unfortunately, susceptibility tests were only made in 3 of the other patients who were not cured; the sensitivity to spiramycin had remained unchanged in these patients.

In the present study, no correlation has been demonstrated between the in vitro susceptibility to spiramycin and the results of treatment. The susceptibility of the 96 strains examined $\left(\mathrm{IC}_{50}\right)$ varied by a factor of 32 from $0.05 \mu \mathrm{g}$. to $1.60 \mu \mathrm{g}$. Hirsch and Finland (1960), examining 36 gonococcal strains, found an eight-fold variation, namely, from $0.4 \mu \mathrm{g}$. to $3.1 \mu \mathrm{g} . / \mathrm{ml}$. Roiron and others (1961) found that the MIC (minimal inhibitory concentration) in 61 gonococcal strains varied by a factor of $10(0 \cdot 12-1 \cdot 0$ $\mu \mathrm{g} . / \mathrm{ml}$.). As the MIC is approximately twice the $\mathrm{IC}_{50}$, there is quite good agreement between these three investigations. No estimation of the spiramycin concentration in patient sera was made in the present study. Chabbert (1955) found a mean concentration 
in the blood ( 7 adult patients) of $2 \cdot 7,2 \cdot 8$, and $1 \cdot 6$ $\mu \mathrm{g} . / \mathrm{ml}$., one, two, and six hours after the ingestion of 3 g. daily. Siboulet and Durel (1961), as mentioned, found a mean value in the serum of approximately 1-2 $\mu \mathrm{g} . / \mathrm{ml}$. during a period of 0-6 hours following the ingestion of $2.5 \mathrm{~g}$. spiramycin in a single dose, but the individual variation does not appear from their study. It is known in the case of other antibiotics (particularly penicillin) that the individual variation can be high (Juncher and Raaschou, 1951; Andresen, 1955; Pellerat, Maillard, and Carron, 1961; Jensen, Lund, and Marner, 1962; Bond, Lightbown, Barber, and Waterworth, 1963; Knudsen and Perdrup, 1963; Yourassowsky, 1963; Schmidt and Roholt, 1965). An individual variation of the spiramycin concentration in serum of the same order of magnitude as the variation in the in vitro susceptibility would obscure any possible correlation between the in vitro and in vivo results. The results will also be affected by other individual factors.

An observation of considerable interest is that all the patients who were not cured were infected with gonococcal strains possessing reduced susceptibility to penicillin. Thus, the present study would appear to show that the outlook for cure following spiramycin treatment is dependent only on the in vitro susceptibility of the gonococcal strain to penicillin.

A reason for this peculiar phenomenon might be that in strains with reduced in vitro susceptibility to penicillin, metabolic conditions were present of a nature that would also reduce the susceptibility of these strains to spiramycin in vivo. The absence of any chemical relationship between spiramycin and penicillin does not exclude such a condition, supposedly based on genetic changes, that would simultaneously involve further metabolic changes (Welsch, 1955). This might, for example, result in the survival of bacteria in closed foci, and thus reduce the possibility of their being attacked by the spiramycin. Watson (1957), for example, found that spiramycin penetrated with difficulty through fibrin membranes. Results from the few cases of meningococcal meningitis treated with spiramycin have also been so poor that the use of the drug is contra-indicated for the treatment of meningitis (May \& Baker, 1964). Poor penetration might also explain why the present study failed to demonstrate any correlation between in vitro susceptibility to spiramycin and the result of treatment with this drug in the case of strains with reduced susceptibility to penicillin (Table VI, last column).

In the case of penicillin, streptomycin, and tetracycline, the relation between the in vitro susceptibility of gonococci to these various antibiotics corresponds to what has been previously found in this country (Reyn, 1961a, b, 1963a, b; Schmidt and Olesen Larsen, 1962). Resistance to streptomycin and reduced susceptibility to tetracycline have virtually been found only in strains with reduced susceptibility to penicillin. This correlation could be explained as a result of a selection in treatment, starting with penicillin, and only using streptomycin or tetracycline for treatment of those cases in which the penicillin treatment failed (cf. Reyn and Korner, 1958; Reyn, Korner, and Bentzon, 1958). In the case of spiramycin, not previously in use in Denmark, the results can hardly be affected by a successive selection of this nature. In the present study, a positive correlation was found between the susceptibility to spiramycin and each of the other three antibiotics. It is possible that in each case the correlation is a reflection of the same factor, the result of the mutual dependence of these antibiotics. It is worthy of note, however, that a correlation can be demonstrated between spiramycin and tetracycline in strains which show both resistance to streptomycin and reduced susceptibility to penicillin.

The possibility must be considered that the cure rate in the present material might have been increased by using a higher daily dose of spiramycin and administration of this drug over a longer period of time. A single 24-hour dose of more than $4 \mathrm{~g}$. has not been reported. Most previous investigators treating gonorrhoea by means of spiramycin have used $2.5 \mathrm{~g}$., administered as a single dose, and in the presence of the physician, just as in the present study, and Willcox (1956) found that $2 \mathrm{~g}$. in a single dose was unsatisfactory,

If this dose is increased as a result of repeated administration during the course of the day, the control which has been achieved by the procedure used in this and other studies is lost, namely, the certainty that the patient does actually consume the drug.

\section{Summary}

Ninety-six patients, 30 women and 66 men, with acute newly diagnosed, uncomplicated gonorrhoea, were treated with $2.5 \mathrm{~g}$. spiramycin in a single dose; 18 defaulted. Of the remaining 78 patients, 65 were cured ( 83 per cent.). All the patients who were not cured were infected with gonococcal strains possessing reduced susceptibility to penicillin. No correlation was demonstrated between the in vitro susceptibility to spiramycin and the result of treatment. Possible reasons for this apparent independence between the result of treatment and the in vitro susceptibility to spiramycin are discussed. 
Grateful acknowledgements are expressed to Messrs. May and Baker Ltd. for kindly providing the spiramycin used in this study.

\section{REFERENCES}

Andresen, P. (1955). Ugeskr. Lag., 117, 1365.

Aurangabadkar, J. W., and Yawalkar, S. J. (1964). Indian J. Derm. Venereol., 30, 60.

Bond, J. M., Lightbown, J. W., Barber, M., and Waterworth, P. M. (1963). Brit. med. J., 2, 956.

Chabbert, Y. (1955). Ann. Inst. Pasteur, 89, 434.

Clarke, G. H. V. (1964). Brit. J. vener. Dis., 40, 122.

David, N. A., and Porter, G. A. (1958-59). Antibiot. Ann., p. 188. Medical Encyclopedia, New York.

Foged, P. (1958). Nord. Med., 59, 356.

Hirsch, H. A., and Finland, M. (1960). Amer. J. med. Sci., 239, 41.

Jensen, P. E., Kvorning, S. A., and Nørredam, K. (1963). Brit. J. vener. Dis., 39, 238.

Jensen, S. F., Lund, E., and Marner, I. L. (1962). Acta path. microbiol. scand., 55, 79.

Juncher, H. O., and Raaschou, F. (1951). Ugeskr. Lag., 113,1221

Knudsen, H. E., and Perdrup, A. (1963), Acta derm.venereol. (Stockh.), 43, 235.

Lind, I. (1964). Ugeskr. Lag., 126, 637.

Lomholt, G., and Berg, O. (1965), Ibid., 127, 457.

May \& Baker Ltd. (1964). Rovamycin (Spiramycin). Oral Antibiotic Therapy. May \& Baker, Dagenham.

Nielsen, K., and Schmidt, H. (1962). Månedsskr. prakt. Lagegern., p. 337.

Pellerat, J., Maillard, M. A., and Carron, R. (1961). Brit. J. vener. Dis., 37, 252.

Pinnert-Sindico, S. (1954). Ann. Inst. Pasteur, 87, 702.

Reyn, A. (1961a). Brit. J. vener. Dis., 37, 145. (1961b). Ugeskr. Lag., 123, 776.

(1963a).Proceedings XII International Congress of Dermatology, Washington D.C., September, 1962, vol. 2, p. 926. (ed. D. M. Pillsbury and C. Livingood). International Congress Series, No. 55. Excerpta Medica Foundation, Amsterdam.
Reyn, A. (1963b). Acta derm.-venereol. (Stockh.), 43, 380. and Bentzon, M. W. (1963). Ibid., 43, 394.

,-- , and Ericsson, H. (1963). Acta path. microbiol. scand., 57, 235.

- and Korner, B. (1958). Månedsskr. prakt. Lagegern., 36, 523. , and Bentzon, M. W. (1958). Brit. J. vener. Dis., 34, 227

Roiron, V., Rasetti-Nicod, G., and Durel, P. (1961). Ann. Inst. Pasteur, 100, 445.

Schmidt, H. (1961). Ugeskr. Lagg., 123, 749. (1962). Nord. Med., 68, 1479.

- and Larsen, S. Oleson (1962). Acta derm.-venereol. (Stockh.), 42, 294 and Roholt, K. (1965). Ugeskr. Laeg., 127, 478.

Siboulet, A., and Durel, P. (1961). Brit. J. vener. Dis. $37,240$.

Watson, K. C. (1957). Brit. J. exp. Path., 38, 493.

Welsch, M. (1955). Antibiot. et Chemother. (Basel), 2, 34.

Willcox, R. R. (1956). Brit. J. vener. Dis., 32, 117.

Yourassowsky, E. C. (1963). Acta clin. belg., 18, 62.

La spiramycine dans le traitement de la gonorrhée aiguë

\section{RÉSUMÉ}

On traita 96 malades, 30 femmes et 66 hommes atteints de gonorrhée aiguë non compliquée, récemment diagnostiquée, par une dose unique de $2,5 \mathrm{~g}$. de spiramycine; 18 ne se présentèrent pas pour le contrôle. Parmi les 78 restants, 65 furent guéris $(83 \%)$. Tous les malades qui ne furent pas guéris étaient infectés par des souches de gonocoque possédant une sensibilité réduite à la pénicilline. On ne trouva pas de rapport entre la sensibilité du microbe in vitro à la spiramycine, et les résultats du traitement. On discute les raisons possibles de cette indépendance apparente entre les résultats du traitement et la sensibilité à la spiramycine in vitro. 